\title{
Digitalization of Payroll System in PT XYZ to Improve Employee Performance
}

\author{
Taufik Salim ${ }^{1}$, Yosef Budi Susanto ${ }^{2}$, So Yohanes Jimmy ${ }^{3}$ \\ \{taufik.salim@student.umn.ac.id ${ }^{1}$, bsusanto@umn.ac.id², yoh.jimmy@gmail.com ${ }^{3}$ \}
}

Magister Management Technology, Multimedia Nusantara University, Indonesia ${ }^{1,2,3}$

\begin{abstract}
To maximize the performance of the company, especially in parts of the payroll, companies had many ways to tackle this problem, like using digital technology. The objective of implementing the digital transformation project is to improve the payroll system at PT XYZ. Currently the salary payment system is still manual, causing problems in the payroll of every employee. Employees at PT XYZ complained about the calculation of the salary calculated by the employee and the HRD. As these problems arise, employee performance deteriorates.To maximize company performance, especially the payroll department, companies can overcome this problem by changing the payroll system with a digitizing system. This study is using quantitative, distributing questionnaires, and conduct interview with top management. It can be concluded that there is a gap between current Digital Maturity Model and future Digital Maturity Model, because that we need transformation technology digital to improve employee performance.
\end{abstract}

Keywords: Digitalization of payroll system, transformation digital technology, payroll system, worker's attendance.

\section{Introduction}

According to [1] Transformation digital defined as the use of technology with the aim of generally increasing the performance or reach of a company. Another definition is also given by [2] which transformation digital he third and highest level of digital skills achieved when digital use is carried out also facilitates innovation and creativity and encourages significant change in the professional or knowledge field. Different meaning with general meaning about transformation change caused or influenced by the use of digital technology in every aspect of human life according to [3]. According to [4] activity of the business and implementation of data processing can be mutually related continuous due to the existence of the payroll system. With this payroll information system, payroll division would be able to keep a record of employees including their personnel data, pay slips, allowances, tax, leave, etc. According to [5] payroll in each company is the riskiest thing; this is caused by the dependence of an employee's life. In various companies in the world, work related leave and payroll handling are in form of a paper work, in order to diminish paper work and to overcome time consuming management.

This paper is purpose to make roadmap transformation digital in PT XYZ because has problems related to the attendance system and improves the performance of the company's success and maximizes profits from the company. Problems that occur are human errors in the payroll system every month. These errors greatly affect employee performance. To overcome this problem, it is done through digital transformation, so that PT XYZ can achieve increased business performance. By checking to minimize existing problems. PT XYZ uses an attendance 
system and software called Sleekr along with a Mugen brand fingerprint scan to eliminate the current problem.

\section{Literature Review}

In the research conducted, the DTP stage will be carried out, namely by identifying problems, looking for capabilities related to these problems, determining relevant DMM dimensions, measuring current and future DMMs, developing initiatives for transformation, and making roadmaps. All stages are carried out to get the results needed to transform digital technology into a payroll system at PT XYZ.

For the stage of identifying problems, researchers conducted research on problems that occurred such as payroll system errors. In looking for capabilities related to these problems, be seen from the capabilities table. After that, measure the current and future DMM by distributing questionnaires, then conducting interviews to find out what kind of expectations the company wants. After that, develop initiatives for transformation, and create a roadmap to find out the flow of the digital technology transformation plan.

\section{Methodology and Data Analysis}

\subsection{Sample and Data Collection}

PT XYZ is a company engaged in chemical flooring that uses chemicals for buildings in the form of floor coating, mortar, waterproofing, and roadmarking. PT XYZ is a subsidiary of Silikal GmbH headquartered in Mainhausen, Germany. Silikal GmbH itself was founded in 1951. In fact, the company Silikal GmbH was only engaged in screed construction. A screed is a smooth top layer on a concrete floor or other surface. This layer can be stucco, wood or other materials. In the 1960s, Silikal GmbH developed new products based on modern synthetic resins for the dynamically growing construction sector, particularly for floor coatings and engineering applications in commerce and industry.

PT XYZ had vision dan misison. Vision is to be the leading company in chemical construction industry. And the mission is to promote and provide better construction system in the food \& beverage industry. PT XYZ has target consumen. The target is various kinds of industries such as hospitality, restaurant, automotive, and others.

\subsection{Current DMM and Future DMM}

In measuring the current state and the situation in the future, a questionnaire is needed at the first stage. Questionnaires were distributed to see what the current situation in the company was. The next stage is to make validity and reliable tests on questionnaires that have been distributed to 30 respondents. After that, take measurements of the situation to come. The measurement is by conducting interviews with the owner. Interviews were conducted to see the conditions expected by the company. After that it can be seen that there is a gap between present and future. Because there is a gap, digital technology transformation is needed.

\subsection{The Respondents}

In distributing questionnaires to determine current DMM, researchers distributed to 30 respondents consisting of 20 staff and 10 managerial levels. After that doing the test of validity 
and reliable, because we want to know all dimension in questionnaires are valid and reliable. The test for validity with Pearson correlation and reliability test with Cronbach alpha, and the results is valid and realible. Meanwhile, prospective DMM respondents were conducted by conducting interviews with the owners.

\section{Research Result \& Discussions}

PT XYZ's priority is to solve problems related to the attendance system and improve company performance and maximize profits from the company. To overcome these problems through digital transformation, the PT XYZ report can achieve increased business performance. By checking to minimize existing problems. PT XYZ uses well-known attendance systems and software such as Sleekr to minimize ongoing problems.

From the table of business capability, the authors choose HR management, customer relationship management, information analysis, reporting and sharing of insights, as well as strategies and directions for developing business capabilities that must be improved. With the funds that have been determined, the company hopes to change the payroll and attendance systems by using digital technology transformation so that the same mistakes do not occur and are detrimental to employees.

Every indicator has been tested for validity with Pearson Correlation and reliability test with Cronbach Alpha, and the results are valid and realible. Table 1 below is the results of testing the validity and reliability of customers, strategies, technology, operations and organizational culture:

Table 1. Result of Test Validity and Reliability

\begin{tabular}{|c|c|c|c|c|c|c|c|}
\hline & \multirow[t]{2}{*}{ Variable } & \multirow[t]{2}{*}{ Indicator } & \multirow[t]{2}{*}{ Code } & \multicolumn{2}{|c|}{ Validity Test } & \multicolumn{2}{|c|}{ Reliability Test } \\
\hline & & & & $\begin{array}{l}\text { Pearson } \\
\text { correlation }\end{array}$ & Result & $\begin{array}{l}\text { Cronbach } \\
\text { Alpha }\end{array}$ & Result \\
\hline 1 & Customer & Employee Trust & CET & $0.835 * *$ & Valid & 0.706 & Reliable \\
\hline 2 & & $\begin{array}{l}\text { Low Employee } \\
\text { Satisfaction }\end{array}$ & CLES & $0.378 *$ & Valid & & \\
\hline 3 & & Complaint & $\mathrm{CC}$ & $0.632 * *$ & Valid & & \\
\hline 4 & & $\begin{array}{l}\text { Privacy and Data } \\
\text { Trust }\end{array}$ & CPADT & $0.632 * *$ & Valid & & \\
\hline 5 & & Fulfilment Trust & CFT & $0.835 * *$ & Valid & & \\
\hline 6 & Strategy & $\begin{array}{l}\text { Strategy } \\
\text { Alignment }\end{array}$ & SSA & $0.798 * *$ & Valid & 0.6 & Reliable \\
\hline 7 & & Digital Roadmap & SDR & $0.516 * *$ & Valid & & \\
\hline 8 & & $\begin{array}{l}\text { Executive } \\
\text { Reporting }\end{array}$ & SER & $0.894 * *$ & Valid & & \\
\hline 9 & Technology & Agility & TA & $0.893 * *$ & Valid & 0.75 & Reliable \\
\hline 10 & & Complaint & TOM & $0.896^{* *}$ & Valid & & \\
\hline 11 & Operation & $\begin{array}{l}\text { Privacy and Data } \\
\text { Trust }\end{array}$ & OPE & $0.718 * *$ & Valid & 0.589 & Reliable \\
\hline 12 & & Fulfilment Trust & OPA & $0.656 * *$ & Valid & & \\
\hline
\end{tabular}




\begin{tabular}{llllllll}
13 & & $\begin{array}{l}\text { Strategy } \\
\text { Alignment }\end{array}$ & OPD & $0.837^{* *}$ & Valid & & \\
\hline 14 & $\begin{array}{l}\text { Organizatio } \\
\text { nal Culture }\end{array}$ & Digital Roadmap & OCDD & $0.821^{* *}$ & Valid & 0.669 & Reliable \\
15 & & $\begin{array}{l}\text { Executive } \\
\text { Reporting } \\
\text { Agility }\end{array}$ & OCTA & $0.3 * *$ & - & & \\
16 & & OCTD & $0.912^{* *}$ & Valid & & \\
\hline
\end{tabular}

$\mathrm{N}=20$

$* * p<.01$, two-tailed. $* p<.05$, two-tailed.

Table 2 below is the current level of DMM at PT XYZ which is measured from 5 dimensions and 16 sub dimensions using a Likert scale 1-5 which will be seen on average in the DMM TM forum:

Table 2. Current DMM Level

\begin{tabular}{|c|c|c|c|c|c|c|}
\hline & Variable & Indicator & Code & $\begin{array}{l}\text { Mean- } \\
\text { Indica } \\
\text { tor }\end{array}$ & $\begin{array}{l}\text { Mean- } \\
\text { Variable }\end{array}$ & Category \\
\hline 1 & Customer & Employee Trust & CET & 2.13 & 3.59 & Performing \\
\hline 2 & & $\begin{array}{l}\text { Low Employee } \\
\text { Satisfaction }\end{array}$ & CLES & 4.6 & & \\
\hline 3 & & Complaint & $\mathrm{CC}$ & 4.53 & & \\
\hline 4 & & $\begin{array}{l}\text { Privacy and Data } \\
\text { Trust }\end{array}$ & CPADT & 4.53 & & \\
\hline 5 & & Fulfilment Trust & CFT & 2.13 & & \\
\hline 6 & Strategy & Strategy Alignment & SSA & 2.1 & 2.62 & Emerging \\
\hline 7 & & Digital Roadmap & SDR & 2.33 & & \\
\hline 8 & & Executive Reporting & SER & 2.97 & & \\
\hline 9 & Technology & Agility & TA & 4.03 & 3.16 & Performing \\
\hline 10 & & Complaint & TOM & 3.87 & & \\
\hline 11 & Operation & $\begin{array}{l}\text { Privacy and Data } \\
\text { Trust }\end{array}$ & OPE & 2.07 & 2.85 & Emerging \\
\hline 12 & & Fulfilment Trust & OPA & 2.23 & & \\
\hline 13 & & Strategy Alignment & OPD & 2.9 & & \\
\hline 14 & $\begin{array}{l}\text { Organizational } \\
\text { Culture }\end{array}$ & Digital Roadmap & OCDD & 2.8 & 2.61 & Performing \\
\hline 15 & & Executive Reporting & OCTA & 1.57 & & \\
\hline 16 & & Agility & OCTD & 2.93 & & \\
\hline
\end{tabular}

$\mathrm{N}=20$ 


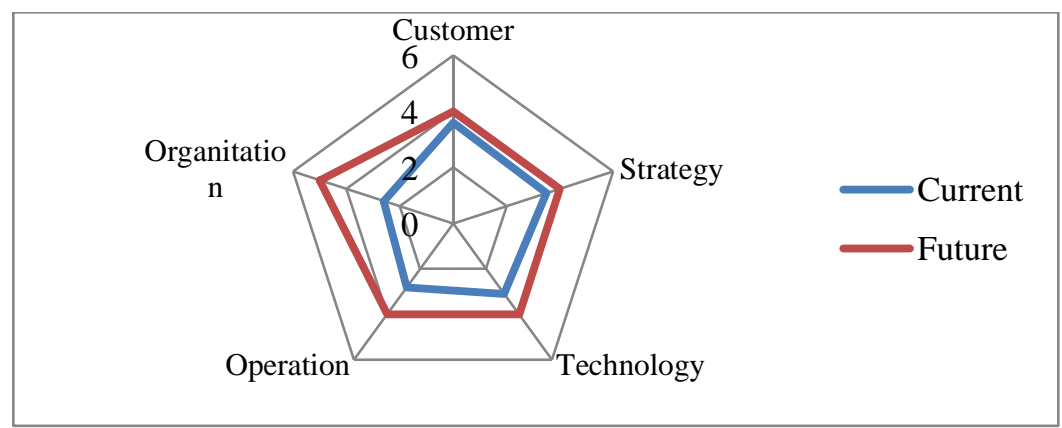

Figure 1. Summary level DMM Future

Based on the results of interviews with the owner of PT XYZ regarding the level of expectations the company wants in the future, it can be seen that on each target from 4 dimensions, namely customers, strategy, technology, operations are at number 4. and for organizations at number 5 .

After looking at the current and future conditions, there is a gap between the current and future conditions. Because of this gap, it is necessary to transform digital technology such as the use of Sleekr software to overcome this gap. The use of Sleekr software is expected to reach the level of expectations desired by the company in the future.

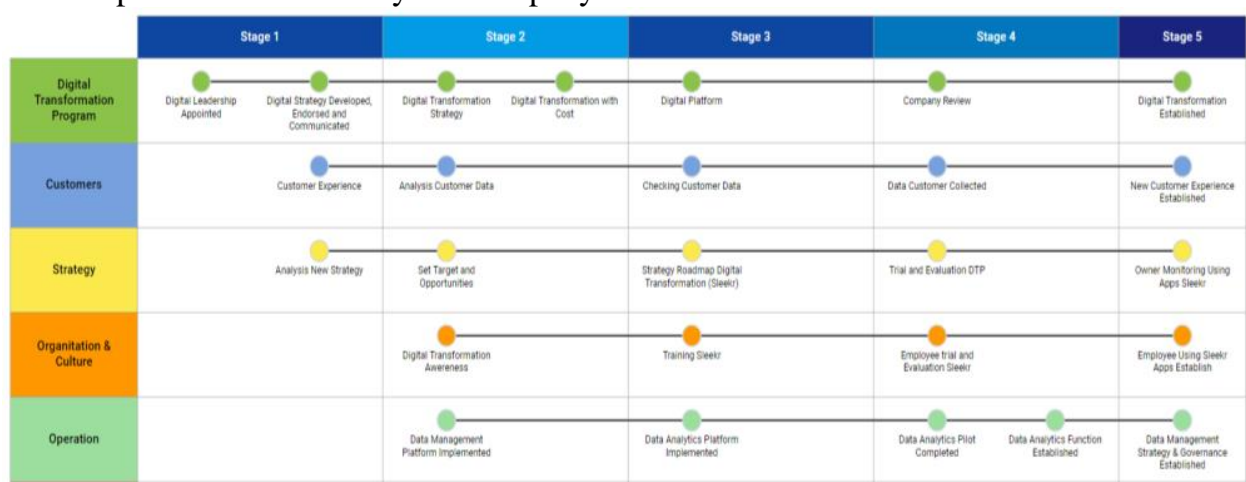

Table Roadmap

Base on roadmap, we can concluded that in stage one, digital transformation program is like make a digital leadership appointed and than continue to digital strategy developmend and communicated. The second stage of digital transformation program is making digital transformation strategy and with cost. The third stage of digital transformation program is making digital platform, after that in the next stage company review for the digital platform. The last stage digital transformation program established. In customers, the first stage is checking customer experience. The second stage is analysis customer data. The third stage is checking customer data. after that in the next stage is all data collected. And the last stage is new costumer experience established. In strategy, the first stage is making new analysis strategy. The second stage is set the target and opportunities. The third stage is making starategy roadmap digital transformation with Sleekr. After that, trial and evaluated DTP. And the last stage is the owner monitoring using Sleekr application. In organitation and culture, the second stage is checking digital transformation awereness. The third stage is doing training employee to use sleekr. After that, the employee trial and evaluation sleekr. The last stage is all employe using sleekr to do attendence and checking salary. In operation, the second stage is data management 
platform implemented. The next stage is data analysis platform implemented. After that data analysis plot dan function completed. The last stage is data management strategy established.

\section{Conclusion, Implications, Limitations, and Suggestions for Further Research}

It can be concluded that PT XYZ has a problem in the payroll section. Problems occur because there are often errors in entering attendance data which can affect employee salaries. To prevent this problem, digital technology transformation is needed, such as the use of Sleekr software. It is hoped that the use of Sleekr software and fingerprint scanning tools can overcome the existing problems.

For the next researchers, it is hoped that they can check again whether the payroll system change strategy is working well or not. If there are still errors, the researcher hopes that the next researcher can solve it in a different way. This research was conducted to change the manual payroll system using digital technology transformation.

\section{References}

[1] G. Westerman, C. Calméjane, D. Bonnet, P. Ferraris, and A. McAfee, "Digital Transformation: A Roadmap for Billion Dollar Organization," MIT Cent. Digit. Bus. Capgemini Consult., 2011.

[2] C. Lankshear and M. Knobel, Digital literacies: Concepts, policies and practices. Peter Lang Publishing, 2008.

[3] B. Kaplan, D. P. Truex, D. Wastell, A. T. Wood-Harper, and J. I. DeGross, "Information systems research: Relevant theory and informed practice," in IFIP Advances in Information and Communication Technology, 2010.

[4] A. Kawale, H. Muthmare, P. Devghare, Y. Rajbhoj, and D. B. Sonkusare, Rajat Khadse, "Automatic Payroll Processing System," Int. J. Sci. Res. Sci. Eng. Technol. IJSRSET, vol. 4, no. 4, pp. 567-570, 2018.

[5] M. Singh, P. Singh, R. Singh, S. Singh, and S. Gupta, "Leave and Payroll Management System," IOSR J. Comput. Eng., vol. 1, no. e-ISSN: 2278-0661,p-ISSN: 2278-8727, pp. 62-66, 2017. 